\title{
Catalytic Wet Air Oxidation of Oxalic Acid using Platinum Catalysts in Bubble Column Reactor: A Review
}

\author{
S. Roy*, M. Vashishtha and A. K. Saroha \\ Department of Chemical Engineering, Indian Institute of Technology, Delhi, New Delhi-110016, India.
}

Received 3 December 2009; Revised 25 February 2010; Accepted 30 April 2010

\begin{abstract}
Wastewater treatment and re-use of industrial process water are critical issue for the development of human activities and environment conservation. Catalytic wet air oxidation (CWAO) is an attractive and useful technique for treatment of effluents where the concentrations of organic pollutants are too low, for the incineration and other pollution control techniques to be economically feasible and when biological treatments are ineffective, e.g. in the case of toxic effluents. In CWAO, combustion takes place on a $\mathrm{Pt} / \mathrm{Al}_{2} \mathrm{O}_{3}$ catalysts usually at temperatures several degrees below those required for thermal incineration. In CWAO process, the organic contaminants dissolved in water are either partially degraded by means of an oxidizing agent into biodegradable intermediates or mineralized into innocuous inorganic compounds such as $\mathrm{CO}_{2}$, $\mathrm{H}_{2} \mathrm{O}$ and inorganic salts, which remain in the aqueous phase. In contrast to other thermal processes CWAO produces no $\mathrm{NO}_{\mathrm{x}}$, $\mathrm{SO}_{2}, \mathrm{HCl}$, dioxins, furans, fly ash, etc. This review paper presents the application of platinum catalysts in bubble column reactor for CWAO of oxalic acid.
\end{abstract}

Keywords: Bubble column reactor; Catalytic wet air oxidation; Oxalic acid; Platinum catalysts.

\section{Introduction}

Water is the most precious natural resource that exists on our planet as over $70 \%$ of the Earth's surface is covered by water. The oceans contain $97 \%$ of the earth's water, while the remaining $3 \%$ is classified as fresh water. Seventy-nine percent of this surface fresh water is stored as ice and glaciers and $20 \%$ as groundwater. The remaining freshwater, which is about $1 \%$ of the world's total, is contained in lakes, rivers, soil moisture etc., as shown in Figure 1. Thus, it can be seen that the water available for use by human beings is very
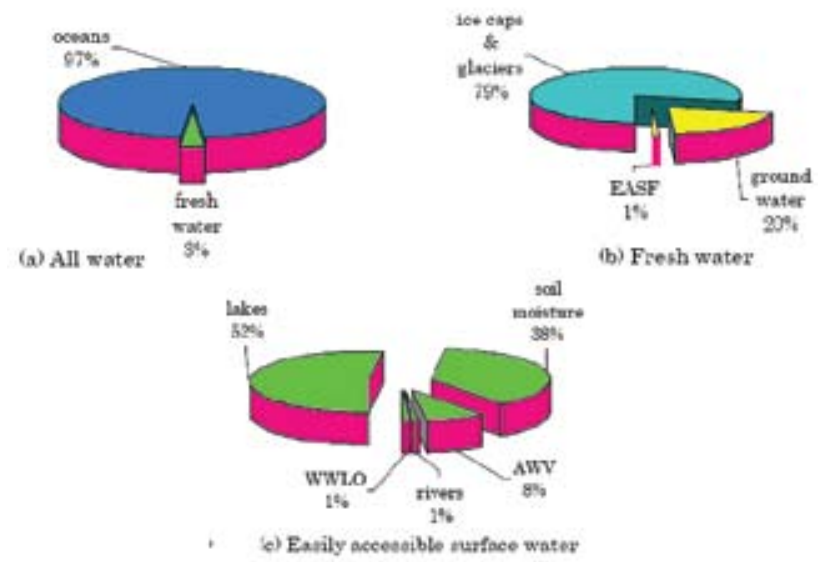

Figure 1. Distribution of the world's water

*E-mail address: shyamalroy78@yahoo.co.in

ISSN: 1791-2377 (C) 2010 Kavala Institute of Technology. All rights reserved. small and as such every effort must be made to be protect it from all forms of contamination.

Surface water is the source for drinking water, irrigation water for agricultural activities, and process water for industrial activities. Due to immense importance of water for day to day survival, human settlement and development has concentrated around water resources. As such the most densely populated and commercially developed areas are located on the shorelines of oceans, lakes and rivers [1].

Although on one hand this fact is recognized, on the other hand it is disregarded by polluting rivers, lakes and oceans, since the same water bodies are used as depository of wastes. During use, water becomes contaminated with various kinds of substances. In many regions, particularly in parts of the developing world, poverty combined with rapid population growth is leading to widespread degradation of water resources. At the same time, rapid urbanization and industrialization in many developing countries is creating high levels of water pollution associated with harmful industrial effluents and sewage discharges. Agricultural activities have contributed to pollution of water receiving bodies due to runoff, which bring with them pesticides and fertilizers [2]. Since the amount of water available for human needs is scanty, it is therefore important to preserve water resources in order to enhance both current and future potential.

In order to manage environmental pollution at global level, 
the United Nations Environmental Program (UNEP) in 1972 was designed to be the "environmental conscience of the United Nations" [3]. In response to this, towards the end of the $20^{\text {th }}$ Century, environmental legislation in most, if not all countries has been enacted to safeguard environmental integrity. Legislation has put in place stringent regulations regarding environmental and health quality standards, especially on the utilization of water resources. However, even with these stringent measures pollution of water resources is still a major problem. In order to combat water pollution, it is important to understand the sources of and problems related to polluting agents.

\subsection{Major Sources of Water Pollution}

Water pollution occurs when a body of water is adversely affected due to the addition of large amounts of material to the water. When it is unfit for its intended use, water is considered to be polluted. The source (Table 1) of water pollution may be a point or a nonpoint source.

Point sources of water pollution occur when harmful or toxic substances are emitted directly into a water body at a single point of discharge. A non-point source delivers pollutants over a wide area. An example of this type of water pollution is when pesticides or fertilizers are washed from agricultural fields by rain, run-off into a water body such as lake or river. While pollution arising from non-point sources accounts for the majority of contaminants in streams and lakes, it is much more difficult to control. The level of nutrients such as nitrates and phosphorus above the acceptable limits in the freshwater ecosystems and toxicity due to pesticides is still a problem in the world.

Table 1. Common water pollutants and their effects [2, 3].

\begin{tabular}{|c|c|c|}
\hline POLLUTANT & $\begin{array}{l}\text { PRIMARY } \\
\text { SOURCE }\end{array}$ & EFFECTS \\
\hline Organic matter & $\begin{array}{l}\text { Industrial wastewater } \\
\text { and domestic sewage }\end{array}$ & $\begin{array}{l}\text { Depletes oxygen from the water } \\
\text { column as it decomposes, stressing or } \\
\text { suffocating aquatic life. }\end{array}$ \\
\hline $\begin{array}{l}\text { Excess nutrients } \\
\text { (nitrates, phospho- } \\
\text { rous) }\end{array}$ & $\begin{array}{l}\text { Run-off from agricul- } \\
\text { tural lands and urban } \\
\text { areas }\end{array}$ & $\begin{array}{l}\text { Over-stimulates growth of algae (a } \\
\text { process called eutrophication), which } \\
\text { then decomposes, robbing the water } \\
\text { oxygen and harming aquatic life. High } \\
\text { levels of nitrates in drinking water lead } \\
\text { to illness in humans }\end{array}$ \\
\hline Heavy metals & $\begin{array}{l}\text { Industries and mining } \\
\text { sites }\end{array}$ & $\begin{array}{l}\text { Persists in freshwater environments, } \\
\text { like river sediments and wetlands, for } \\
\text { long periods. Accumulates in the tissue } \\
\text { of fish and shellfish. Toxic to both } \\
\text { aquatic organisms and humans who } \\
\text { eat them }\end{array}$ \\
\hline $\begin{array}{l}\text { Microbial con- } \\
\text { taminants (e.g. } \\
\text { cryptosporidium, } \\
\text { cholera and other } \\
\text { bacteria, amoebae, } \\
\text { etc.) }\end{array}$ & $\begin{array}{l}\text { Domestic sewage, } \\
\text { cattle, natural sources }\end{array}$ & $\begin{array}{l}\text { Spreads infectious diseases through } \\
\text { contaminated water supplies, causing } \\
\text { millions of cases of diarrhoea diseases } \\
\text { and intestinal parasites, and providing } \\
\text { one of the principal causes of childhood } \\
\text { mortality in the developing world }\end{array}$ \\
\hline $\begin{array}{l}\text { Toxic organic } \\
\text { compounds (oil, } \\
\text { pesticides, some } \\
\text { plastics, industrial } \\
\text { chemicals) }\end{array}$ & $\begin{array}{l}\text { Wide variety of sourc- } \\
\text { es, from industrial } \\
\text { sites, to automobiles, } \\
\text { to farmers and domes- } \\
\text { tic gardeners }\end{array}$ & $\begin{array}{l}\text { Displays a range of toxic effects in } \\
\text { aquatic fauna and humans, from mild } \\
\text { immune suppression, to acute poison- } \\
\text { ing, or reproductive failure }\end{array}$ \\
\hline
\end{tabular}

\begin{tabular}{l|l|l}
$\begin{array}{l}\text { Dissolved salts } \\
\text { (salinization) }\end{array}$ & $\begin{array}{l}\text { Leached from } \\
\text { alkaline soils by over- } \\
\text { irrigation, or drawn } \\
\text { into coastal aquifers } \\
\text { from over-drafting of } \\
\text { groundwater }\end{array}$ & $\begin{array}{l}\text { Leads to salt build-up in soils, which } \\
\text { kills crops or cuts yields. Renders } \\
\text { freshwater supplies undrinkable }\end{array}$ \\
$\begin{array}{l}\text { Deposition of sulphate } \\
\text { particles, mostly from } \\
\text { or acid run-off } \\
\text { coal combustion. Acid } \\
\text { run-off from mine } \\
\text { tailings and sites }\end{array}$ & $\begin{array}{l}\text { Acidifies lakes and streams, which } \\
\text { harms or kills aquatic organisms and } \\
\text { leaches heavy metals such as aluminum } \\
\text { from soils into water bodies }\end{array}$ \\
particles & $\begin{array}{l}\text { Soil erosion and } \\
\text { construction activities } \\
\text { on watersheds }\end{array}$ & $\begin{array}{l}\text { Reduces water quality for drinking } \\
\text { and recreation and degrades aquatic } \\
\text { habitats by smothering them with silt, } \\
\text { disrupting spawning, and interfering } \\
\text { with feeding }\end{array}$ \\
\hline $\begin{array}{l}\text { Thermal pollution } \\
\text { Fragmentation of } \\
\text { rivers by dams and } \\
\text { reservoirs, slowing } \\
\text { water and allowing } \\
\text { it to warm. Industrial } \\
\text { uses such as cooling } \\
\text { towers }\end{array}$ & $\begin{array}{l}\text { Affects oxygen levels and decomposi- } \\
\text { tion rate of organic matter in water } \\
\text { column. May shift the species composi- } \\
\text { tion of a river or lake }\end{array}$ \\
\hline
\end{tabular}

\subsection{Industrial Wastewater}

Industrial activities have been fast expanding for the past decades. These industries include, among others, petrochemical, chemical, and pharmaceutical industries, which use both natural and synthetic organic chemicals. Water pollution is caused by both synthesis and the application of industrial products in such areas as: nutrition, transportation, accommodation and energy exploitation. Although not always acknowledged, chemical activity is indispensable to sustaining life; also it is needed to achieve and maintain a high standard of living. Examples of products needed in modern life include medicaments, cleaning and disinfecting products, cosmetics, stabilizers, artificial fertilizers, pesticides, fuel, batteries, polymers (thermoplastics, thermosetting resins, elastomers, fibres), paint and dyes. These product classes inevitably result into pollution during their production, use and disposal [4].

Improper discharge of wastewater containing toxic organic compounds such as oxalic acid presents a major threat to the environment and must be prevented because of the extreme toxicity to aquatic life. These reasons call for the development of more feasible, effective and efficient effluent treatment technologies, which accomplish the destruction of these wastes into non-toxic or biodegradable end products.

\section{Oxalic Acid}

Oxalic acid is the chemical compound with the formula $\mathrm{H}_{2} \mathrm{C}_{2} \mathrm{O}_{4}$. This dicarboxylic acid is better described with the formula HOOC$\mathrm{COOH}$. It is a relatively strong organic acid, being about 3,000 times stronger than acetic acid. The di-anion, known as oxalate, is also a reducing agent as well as a ligand in coordination chemistry. Many metal ions form insoluble precipitates with oxalate, a prominent example being calcium oxalate, which is the primary constituent of the most common kind of kidney stone. Oxalic acid is commercially available as the dehydrate containing $28.5 \%$ water. Oxalic acid finds application as automobile radiator cleaner, 
general metal and equipment cleaning, purifying agent, intermediate for many compounds in leather tanning, in bleaching of textiles ,stepping agent for permanent press resins etc. Its major consumer industries are ink, textile and metal cleaning. Oxalic acid and its salts are also used as reagents in chemical analysis. International demand for oxalic acid is around 0.25 million tonnes per annum.

\subsection{Effect of Oxalic acid on human health}

The affinity of divalent metal ions is sometimes reflected in their tendency to form insoluble precipitates. Thus in the body, oxalic acid also combines with metals ions such as $\mathrm{Ca}^{2+}, \mathrm{Fe}^{2+}$ and $\mathrm{Mg}^{2+}$ to deposit crystals of the corresponding oxalates, which irritate the gut and kidneys. Because it binds vital nutrients such as calcium, longterm consumption of foods high in oxalic acid can be problematic. Healthy individuals can safely consume such foods in moderation, but those with kidney disorders, gout, rheumatoid arthritis, or certain forms of chronic vulvar pain (vulvodynia) are typically advised to avoid foods high in oxalic acid or oxalates. The calcium oxalate precipitate (better known as kidney stones) obstructs the kidney tubules. Conversely, calcium supplements taken along with foods high in oxalic acid can cause calcium oxalate to precipitate out in the gut and drastically reduce the levels of oxalate absorbed by the body (by $97 \%$ in some cases.) $[5,6]$. Oxalic acid can also be produced by the metabolism of ethylene glycol ("antifreeze"), glyoxylic acid or ascorbic acid (vitamin C). Some Aspergillus species produce oxalic acid, which reacts with blood or tissue calcium to precipitate calcium oxalate [7]. There is some preliminary evidence that the administration of probiotics can affect oxalic acid excretion rates (and presumably oxalic acid levels as well) [8].

\subsection{Comparison between different wastewater treatment methods}

The sustainable water management is one of the critical issues to be addressed in the coming decades. Up to date, more than half of the available freshwater is appropriated for human uses, indicating a high degree of exploitation of the existing water resources. In the close future, the water resources may even suffer drastic variations on a local and/or global level, because of the foreseen population growth and climate changes. This fact, in combination with the water pollution caused by mankind activity, makes water re-use of outmost importance. However, one should keep in mind that, from a global point of view, the recycling of water is not environmentally benign if high energy input technologies are used for this purpose. Thus, the development of efficient wastewater technologies with low energetic and operation costs is essential for all types of wastewater. Wastewater can be divided into four broad categories, according to its origin, namely domestic, industrial, public service and system loss/leakage [9]. Among these, industrial wastewaters occupy a $42.4 \%$ of the total volume and domestic $36.4 \%$. In particular, increasing quantities of wastewater with a high organic load result from numerous industrial and domestic applications. The most common treatment technology in this case is the conventional biological treatment. However, its application becomes impossible for streams that contain high organic load and/or bio-toxic compounds. Oxalic acid and oxalic acid like compounds are frequently encountered in the end of pipe streams of several chemical industries, such as petrochemical, pharmaceutical etc. The importance of these effluents is outlined by the high quantities that are eventually rejected in the environment despite the legislation restrictions.

Various methods have been developed for the remediation of these effluents, the most important being the adsorption on activated carbon, the thermal incineration and the liquid phase chemical oxidation. Adsorption on activated carbon is very effective for a broad range of organic pollutants. It is well known that activated carbon has a large surface area and adsorbs significant quantities of pollutants [10], but it does not ultimately destroy them. An adequate strategy for the spent active carbon disposal or regeneration is required, increasing the operating cost of the method. Incineration is the other well established technology for the treatment of concentrated and toxic organic waste streams. Organic pollutants are burnt at atmospheric pressure and high temperatures between $1000^{\circ} \mathrm{C}$ and $1700^{\circ} \mathrm{C}$ [11]. Thus, incineration can offer almost complete pollutant destruction, although at very high energy costs, because an organic load above $25 \%$ is necessary to guarantee auto thermal oxidation. Furthermore, this technique has been accused for the emission of toxic by-products such as dioxins and furans [12], Liquid phase chemical oxidation methods promise to overcome the existing drawbacks of the above mentioned treatment methods by destroying the pollutant while being dissolved in the liquid phase. Several emerging liquid phase oxidation methods can be distinguished in terms of the different oxidants, catalysts and operating conditions selected. The non-catalytic Wet Air Oxidation (WAO) process uses a gaseous source of oxygen which is the most readily available oxidant. Molecular oxygen can be dissolved in sufficient quantities in the liquid phase, at relatively mild temperatures and pressures above $150^{\circ} \mathrm{C}$ and $2 \mathrm{MPa}$ to oxidize several organic pollutants [13]. Alternatively, more effective, but also more expensive oxidants, like hydrogen peroxide [14] and ozone have been tested, yielding good results at milder conditions.

The incorporation of a catalyst has also been considered in combination with all types of oxidants aiming to reduce the operating temperature and pressure, and/or to treat pollutants that cannot be destroyed during non-catalytic liquid phase oxidation processes. Homogeneous catalysts, such as copper ions in solution are very effective in oxidizing several organics when air is used as an oxidant [15]. The classical Fenton's reaction, which combines iron salts with hydrogen peroxide, has also given good results for various organic pollutants [16]. Nonetheless, the addition of a homogeneous catalyst has the inherent disadvantage of the posterior catalyst removal from the treated effluent, because the metal ions are pollutants themselves in the range of concentrations used. Heterogeneous catalysts, on the other hand, do not need any extra separation step and are thus more attractive. Solid catalysts, mostly noble metals and base metal oxides, have been tested in combination with all types of oxidants. The incorporation of heterogeneous catalysts has exhibited promising results in laboratory tests, but industrial applications have been hindered because of the lack of stable catalytic performance over sufficiently long periods. It has been demonstrated that catalyst deactivation can take place because of the active phase leaching [17], the formation of carbonaceous deposits [18] and, to a less extent, the catalyst sintering [19]. A different way to enhance oxidation, is the application of external energy sources, such as electrical/electrochemical [20], radiation and ultrasound 
[21] to form very reactive $\mathrm{OH} \bullet$ radicals. These methods seem to be mostly adequate for low flow rate and low concentration effluents and the successful removal of target pollutants has been reported even at ambient conditions. Obviously, in this case the heating cost is translated to the cost of producing the respective energy for each process. An ultimate distinction between the different methods is based on the operating conditions. If process temperature and pressure are higher than the critical pressure and temperature of water, then supercritical methods emerge. Supercritical processes are extremely effective, but suffer from corrosion, salt precipitation, as well as high energy requirements [22].

It is well known that the process performance and economics strongly relies on the sound reactor selection and design. Degaleesan et al. [23], in a critical review of the current trends in catalytic reactor engineering, outline the importance of the simultaneous development of both chemistry and engineering aspects for any emerging process. A better understanding of the reactor behavior, would enable to improve the reactor operation and modeling tools, thus eventually minimizing the operation costs and, more important, the scale up risks. The implementation of novel reactor concepts can result in significant improvements in process performance. For example, in supercritical water oxidation innovative reactor configurations, such as the MODAR and the transpiring wall reactors, overcome corrosion and salt precipitation problems [24].

The review of the related research work done in this field, suggests that the process selection should be tailored to the composition of the effluent, the desired conversion and the flow rate. A thorough study of the optimum range of application for each method is a rather difficult task, but future work should be driven in this direction. A first attempt by Andreozzi et al. [25], led to the technology map shown in Figure 2, in which WAO appear to be most suitable for wastewater containing between 20 and $200 \mathrm{~g} / \mathrm{l}$ of COD (Chemical Oxygen Demand).
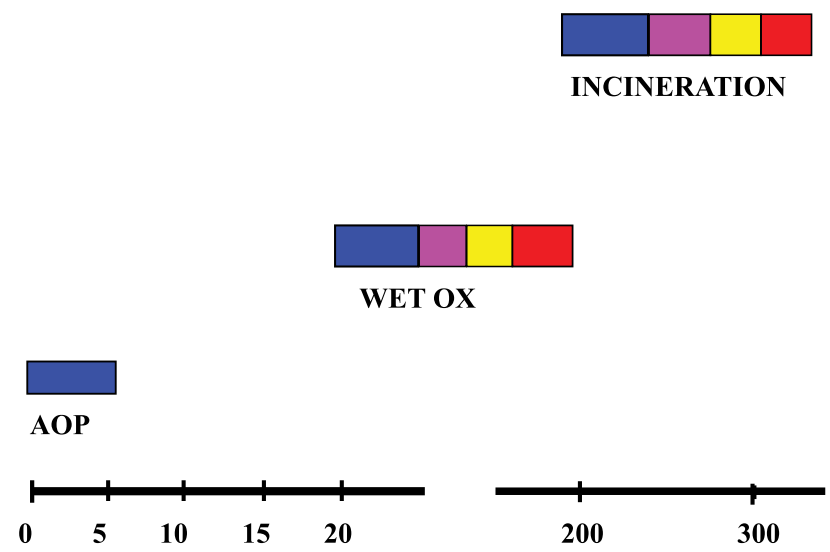

COD (g/l)

Figure 2. Suitability of water technologies according to COD contents [25]

The suitability of WAO would be further reinforced if a heterogeneous catalyst is successfully incorporated in the process. Thus, particular emphasis has to be dedicated to the study of the Catalytic Wet Air Oxidation (CWAO) process.

\section{Wet Air Oxidation}

The incapability of conventional methods to effectively remove many organic pollutants has made it evident that new, compact and more efficient systems are needed. The wet-air or thermal liquid-phase oxidation (WAO) process, in which the generation of active oxygen species, such as hydroxyl radicals, takes place at high temperatures and pressures, is known to have a great potential for the treatment of effluents containing a high content of organic matter (COD, 10-100 g/l), or toxic contaminants for which direct biological purification is unfeasible. In this process, molecular oxygen dissolved in the wastewater reacts with the organic and inorganic pollutants. The oxidizing power of the process is based on the high solubility of oxygen at these severe conditions and the high temperature that increases the reaction rates and production of free radicals.

WAO is used to remove total organic carbon (TOC) such as insoluble polymers, wastewater, and certain organic compounds. The efficient removal of pollutants via WAO process requires very high temperature and pressure, typically in the range $473-573 \mathrm{~K}$ and $7-15 \mathrm{MPa}$, respectively. However, the severe reaction conditions can lead to high installation costs, and limits its practical applications. Therefore, the development of catalytic wet air oxidation (CWAO) using various catalysts has been attempted in order to reduce the severity of the oxidation conditions. The use of catalysts makes the process more attractive by achieving high combustion efficiency at considerably lower temperature and pressure.

\subsection{Fundamentals of Catalytic Wet Air Oxidation (CWAO)}

CWAO is an attractive and useful technique for treatment of effluents where the concentrations of organic pollutants are too low for the incineration process which is not economically feasible due to additional fuel cost or when heat recovery would result in only marginal saving and when biological treatments are ineffective, e.g. in the case of toxic effluents. The combustion takes place on a catalyst usually at temperatures several degrees below those required for thermal incineration. The temperature that is necessary to initiate the reaction depends on the type of pollutant present.

Wastewater treatment based on catalytic oxidation has been growing rapidly, as a powerful method of purifying wastewater. Due to the presence of a catalyst much higher oxidation rates are achieved and consequently, one can use less severe reaction conditions (low temperature and pressure) to reduce chemical oxygen demand to the same degree as in the case of noncatalytic process. In the CWAO process, the organic contaminants dissolved in water are either partially degraded by means of an oxidizing agent into biodegradable intermediates or mineralized into innocuous inorganic compounds such as $\mathrm{CO}_{2}, \mathrm{H}_{2} \mathrm{O}$ and inorganic salts, which remain in the aqueous phase [26, 27]. Sulphur is converted to sulphate, halogens to halides and phosphorus to phosphates. Organic nitrogen may produce ammonia, nitrate and nitrogen. In contrast to other thermal processes CWAO produces no $\mathrm{NO}_{\mathrm{x}}, \mathrm{SO}_{2}, \mathrm{HCI}$, dioxins, furans, flyash, etc.

The challenging operating conditions of WAO provided a strong driving force to investigate catalysts which would allow 
substantial gains on temperature, pressure and residence time. Another major benefit of using catalysts in WAO is the oxidation of the refractory compounds, namely acetic acid and ammonia, at much lower temperatures than in the absence of catalysts. Several crucial issues have to be addressed relating to chemical and physical stability of the heterogeneous oxidation catalysts during WAO such as, leaching and sintering of the active phase and loss of surface area of the support. Leaching can be controlled to a large extent by a proper choice of the catalytic metal or metal oxide according to the available solubility data, and by $\mathrm{pH}$ control during CWAO. The same parameters are also of importance to control the hydrothermal stability of the catalyst carrier. Oxides of $\mathrm{Al}, \mathrm{Hf}, \mathrm{Zr}$, and $\mathrm{Ti}$ have been shown to be stable in super critical water oxygen (SCWO) conditions and should be selected as catalyst supports. However; high surface area metal stable oxides such as $\gamma-\mathrm{Al}_{2} \mathrm{O}_{3}$ could undergo phase transitions detrimental to the durability of the supported catalytic metals and oxides. In addition to these, deactivation factors associated with the physical properties of the liquid phase (temperature, pressure, and $\mathrm{pH}$ ), poisoning of the active sites by deposition of organic or inorganic compounds may also compromise the durability of the catalyst. The first patent was filed by DuPont in 1950 to claim a catalytic composition based on Mn-Zn$\mathrm{Cr}$ oxides to perform CWAO at temperatures in the range of 120$200^{\circ} \mathrm{C}$, for the destructive catalytic oxidation of industrial wastes of an organic nature, to permit their economical disposal, to abate stream pollution, to inhibit stream contamination and to otherwise eliminate industrial and health problems associated therewith. Several types of heterogeneous catalysts were studied in the last decades, based first on supported or unsupported base metal oxides and more recently on supported precious metals [28]. Supported precious metal catalysts are generally less prone to deactivation by leaching of the active phase, and present higher overall activities for the oxidation of various pollutants, especially acetic acid and ammonia. Additional information about academic studies of CWAO can be found in three recent reviews [13, 15, 29].

\subsection{Commercially used CWAO Processes}

The Wet Air Oxidation process was originally developed by F. J. Zimmermann and its first industrial applications appeared in the late 1950s [30]. Currently, there are more than 200 plants operating around the world, the majority being dedicated to the treatment of sewage sludge. Other main fields of application consist in the regeneration of activated carbon and the treatment of industrial wastewater [31]. The development of commercial CWAO processes started as early as the mid-fifties in the United States [32]. In Japan, three CWAO technologies have been developed since the mid-eighties based on heterogeneous catalysts containing precious metals deposited on titania or titania-zirconia carriers. Compared to standard WAO, these processes are able to oxidize two refractory compounds, namely acetic acid and ammonia, thus allowing the treated water to be discharged directly or reused as process water. In Europe, on the other hand, the focus was more on homogeneous CWAO. Several homogeneously catalyzed wet air oxidation processes based on this concept. (e.g., Ciba-Geigy, LOPROX, WPO, ORCAN and ATHOS processes) have been developed in the last two decades [33]. Soluble transition metal catalysts based on iron or copper salts are now being applied in several commercial wet-air oxidation plants, which are operating successfully to treat industrial effluents and sludge. Homogeneous transition metal catalysts, however, need to be separated from the treated wastewater stream and recycled to the reactor inlet or discarded. Therefore, their use has to be evaluated in the existing discharge regulations either in the liquid or solid phases.

In CWAO, the dissolved or suspended organic matter is oxidized in the liquid phase by some gaseous source of oxygen that may be either pure oxygen, or air [13]. Typical operating conditions are in the range of $100-300^{\circ} \mathrm{C}$ and $0.5-20 \mathrm{MPa}$. Some industrial applications, as summarized by Kolaczkowski et al. [31], Luck [32, 33] and Debellefontaine et al.[34], are given in Table 2. The main differences between the distinct processes is in the reactor type used and the use (or not use) of a catalyst.

Table 2. Main industrial processes of Wet Air Oxidation [31, 32, 33].

\begin{tabular}{|c|c|c|c|c|c|c|}
\hline Process & $\begin{array}{c}\text { Waste } \\
\text { type }\end{array}$ & $\begin{array}{c}\text { No. } \\
\text { Plants }\end{array}$ & $\begin{array}{c}\text { Reactor } \\
\text { Type }\end{array}$ & $\mathbf{T}\left({ }^{\circ} \mathrm{C}\right)$ & P(MPa) & Catalyst \\
\hline Zimpro & $\begin{array}{l}\text { sewage } \\
\text { sludge } \\
\text { spent AC } \\
\text { industrial }\end{array}$ & $\begin{array}{c}200 \\
20 \\
50\end{array}$ & $\begin{array}{l}\text { Bubble } \\
\text { Column }\end{array}$ & $280-325$ & 20 & none \\
\hline Vertech & $\begin{array}{l}\text { sewage } \\
\text { sludge }\end{array}$ & 1 & $\begin{array}{l}\text { deep } \\
\text { shaft }\end{array}$ & $<280$ & $<11$ & none \\
\hline Wetox & ns & ns & $\begin{array}{c}\text { stirred } \\
\text { tanks }\end{array}$ & $200-250$ & 4 & none \\
\hline Kenox & ns & ns & $\begin{array}{l}\text { recircu- } \\
\text { lation } \\
\text { reactor }\end{array}$ & $<240$ & 4.5 & none \\
\hline Oxyget & ns & ns & $\begin{array}{c}\text { tubular } \\
\text { jet }\end{array}$ & $<300$ & ns & none \\
\hline $\begin{array}{l}\text { Ciba- } \\
\text { Geigy }\end{array}$ & industrial & 3 & ------- & 300 & ns & $\mathrm{Cu}^{2+}$ \\
\hline LOPROX $^{1}$ & industrial & $>1$ & $\begin{array}{l}\text { Bubble } \\
\text { column }\end{array}$ & $<200$ & $5-20$ & $\mathrm{Fe}^{2+}$ \\
\hline NS-LC & ns & ns & Monolith & 220 & 4 & $\begin{array}{c}\mathrm{Pt}-\mathrm{Pd} / \\
\mathrm{TiO}_{2}- \\
\mathrm{ZrO}_{2}\end{array}$ \\
\hline Osaka gas & $\begin{array}{l}\text { coal } \\
\text { gasifier } \\
\text { coke } \\
\text { oven } \\
\text { cyanide } \\
\text { sewage } \\
\text { sludge }\end{array}$ & ns & $\begin{array}{l}\text { Slurry } \\
\text { Bubble } \\
\text { Column }\end{array}$ & 250 & 7 & $\begin{array}{c}\mathrm{ZrO}_{2} \text { or } \\
\mathrm{TiO}_{2} \\
\text { with } \\
\text { noble or } \\
\text { base } \\
\text { metals }\end{array}$ \\
\hline Kurita $^{2}$ & ammonia & ns & ns & $>100$ & ns & $\begin{array}{c}\text { supported } \\
\mathrm{Pt}\end{array}$ \\
\hline
\end{tabular}

ns: not specified,

${ }^{1}$ This process uses organic quinone substances to generate hydrogen peroxide, ${ }^{2}$ This process uses nitrite as oxidant

The most widespread variation is the non-catalytic Zimpro process, which uses a cocurrent bubble column reactor, operating at temperatures between $147^{\circ} \mathrm{C}-325^{\circ} \mathrm{C}$ and pressures of 2-21 MPa. A simplified flow diagram of the process is given in Figure 3. 


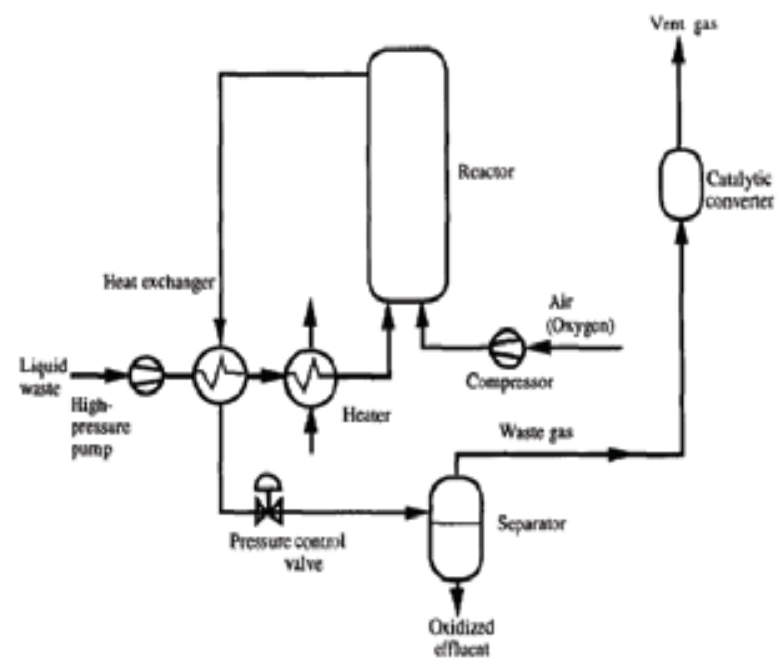

Figure 3. Simplified Zimpro process flow diagram [32]

The main components in the flow diagram are the separate gas and liquid feed lines, the heat exchanger unit, a gas liquid separator and a catalytic converter to destroy any volatile organics remaining in the gas phase. Alternative non-catalytic WAO processes are the Wetox process that combines a series of agitated tank reactors, the Vertech process that uses the gravity to develop high pressures in a deep shaft reactor, the Kenox process which incorporates novel elements like static mixing and ultrasound energy and the Oxyget process in which the liquid is fed in the reactor in form of droplets to eliminate oxygen transfer limitations. WAO can achieve easily 90 to $95 \%$ conversion [34], which in general is not enough to meet effluent discharge regulations. Thus, most of WAO units are followed by biological treatment.

Despite its success in laboratory applications, catalytic WAO has yet not found the industrial recognition met with non-catalytic WAO. The main reasons, as pointed out earlier, are that the homogeneous catalysts have to be removed in a subsequent step, while the heterogeneous catalysts have to maintain their activity for sufficiently long periods. Homogeneous catalysts, such as $\mathrm{Cu}^{2+}$ or $\mathrm{Fe}^{2+}$ ions, are used in the Ciba-Geigy, LOPROX and WPO processes. The former uses $\mathrm{Cu}^{2+}$ ions at elevated temperatures (above $300^{\circ} \mathrm{C}$ ) and is very successful in completely removing dioxins. In the reactor exit the catalyst is precipitated as copper sulphide and recycled to the reactor. The other two processes add $\mathrm{Fe}^{2+}$, in more moderate conditions [32].

The heterogeneous Catalytic WAO has scarcely found industrial applications. The NS-LC process uses a vertical monolith reactor with a $\mathrm{Pt}-\mathrm{Pd} / \mathrm{TiO}_{2}-\mathrm{ZrO}_{2}$ catalyst. The operating conditions are $220^{\circ} \mathrm{C}$ and $4 \mathrm{MPa}$. The Osaka gas process uses a mixture of precious and base metals on titania or zirconia-titania supports. Typical operating conditions are $250^{\circ} \mathrm{C}$ and $6.86 \mathrm{MPa}$. The Kurita process uses nitrite instead of oxygen, and a similar catalyst (supported Pt), becoming more effective at lower temperatures, around $170^{\circ} \mathrm{C}$.

Surprisingly, the industrial applications of CWAO operate at temperatures and pressures that are not significantly lower than those encountered in WAO. However, they use expensive noble metal catalysts. This contradicts with laboratory scale tests that have clearly proven the superior efficiency of CWAO at significantly lower temperatures and pressures [13], yielding less and more biodegradable partial oxidation products [35] [Table 2].

Given the potential of the CWAO, significant efforts have been driven in the last three decades to both develop active and stable catalysts for the process, and describe the reaction kinetics. Conversely, three phase catalytic reactor design and modeling for CWAO has received less attention, although some first trends have been reported.

In the present review, an overview of the current state of art on CWAO catalysts, kinetics and reactor design is attempted to outline both the progress done in the field of CWAO and the key aspects to be addressed by future research work.

\subsection{Catalyst used in Catalytic Wet Air Oxidation Processes}

The heterogeneous catalysts that have been employed in CWAO can be divided in two main groups, i.e. metal oxides (as well as mixtures of them) and supported noble metals [15, 29]. Active carbon, without any deposited active phase, has also exhibited catalytic activity [36].

\subsubsection{Noble Metal based Catalysts}

Noble metals have been very effective in the treatment of different pollutants such as carboxylic acids, including refractory acetic acid [37, 38], ammonia [39, 40] and kraft effluents [41]. Pd, Pt and Ru have received major attention although $\mathrm{Ir}$ or Rh have also been tested $[42,43]$. Table 3 , summarizes the applications of noble metal catalysts in the CWAO.

Table 3. Process data of CWAO using noble catalysts [42, 43].

\begin{tabular}{|c|c|c|c|c|}
\hline & Support & Substrate & $\mathrm{T}\left({ }^{\circ} \mathrm{C}\right)$ & P (MPa) \\
\hline $\mathrm{Pt}$ & $\gamma-\mathrm{Al}_{2} \mathrm{O}_{3}$ & acetic acid & $>200$ & 2 \\
\hline $\begin{array}{l}\text { Ru, Ir, Pd, Ag, } \\
\text { base metals }\end{array}$ & $\begin{array}{c}\mathrm{CeO}_{2}, \mathrm{TiO}_{2}, \\
\mathrm{ZrO}_{2} \\
\end{array}$ & acetic acid & 200 & 2 \\
\hline $\mathrm{Pt}$ & $\gamma-\mathrm{Al}_{2} \mathrm{O}_{3}$ & maleic acid & $>120$ & $>0.4$ \\
\hline $\mathrm{Ru}$ & $\mathrm{CeO}_{2}$ & maleic acid & $>160$ & 2 \\
\hline $\mathrm{Pt}$ & $\mathrm{C}$ & $\begin{array}{c}\text { carboxylic } \\
\text { acids }\end{array}$ & $>20$ & $>0.1$ \\
\hline $\mathrm{Pt}$ & $\mathrm{C}$ & $\begin{array}{c}\text { carboxylic } \\
\text { acids }\end{array}$ & 200 & 0.69 \\
\hline $\mathrm{Pt}$ & $\gamma-\mathrm{Al}_{2} \mathrm{O}_{3}$, resin & $\begin{array}{c}\text { carboxylic } \\
\text { acids }\end{array}$ & 80 & 0.1 \\
\hline Ir & C & butiric acid & 200 & 0.69 \\
\hline $\mathrm{Pt}, \mathrm{Ru}, \mathrm{Rh}$ & $\mathrm{TiO}_{2}, \mathrm{CeO}_{2}, \mathrm{C}$ & $\begin{array}{c}\text { phenol/acrylic } \\
\text { acid }\end{array}$ & 170 & 2 \\
\hline $\mathrm{Pt}$ & $\gamma-\mathrm{Al}_{2} \mathrm{O}_{3}$ & phenol & $>155$ & 2 \\
\hline $\mathrm{Pt}, \mathrm{Ag}$ & $\mathrm{MnO}_{2} / \mathrm{CeO}_{2}$ & phenol & $>80$ & 0.5 \\
\hline $\mathrm{Ru}$ & $\mathrm{C}, \mathrm{CeO}_{2} / \mathrm{C}$ & phenol & 160 & 2 \\
\hline $\mathrm{Pt}$ & $\mathrm{C}$ & p-chlorophenol & 170 & 2.6 \\
\hline $\mathrm{Pt}, \mathrm{Ru}, \mathrm{Pd}, \mathrm{Rh}$ & $\mathrm{CeO}_{2}$ & ammonia & $>150$ & 2 \\
\hline $\mathrm{Pd}$ & $\mathrm{C}$ & ammonia & 280 & 2 \\
\hline $\mathrm{Pt}$ & SDB resin & ammonia & $>110$ & $<0.28$ \\
\hline $\mathrm{Pt}, \mathrm{Ru}, \mathrm{Pd}, \mathrm{Ir}$ & $\mathrm{TiO}_{2}, \mathrm{CeO}_{2}, \mathrm{C}$ & ammonia & $>150$ & 1.5 \\
\hline $\mathrm{Ru}$ & $\mathrm{TiO}_{2}, \mathrm{ZrO}_{2}$ & Kraft effluent & 190 & 5.5 \\
\hline $\mathrm{Pd}-\mathrm{Pt}-\mathrm{Ce}$ & $\gamma-\mathrm{Al}_{2} \mathrm{O}_{3}$ & Kraft effluent & $>130$ & $>1.5$ \\
\hline
\end{tabular}

Among the noble metal catalysts reported for liquid phase oxidation, platinum-supported catalysts seem to be promising. Plati- 
num catalysts are well-known to be effective during aqueous phase oxidation of alcohols [44, 45] and ammonia [39]. However, there is still meager information on the application of platinum catalysts for CWAO of organic pollutants [43, 46, 47]. From Table 3 it is evident that numerous noble metal catalysts are available, but for different pollutants different metals may present optimum results. For example, in the case of acetic acid oxidation, Barbier et al. [37] state that the catalytic activity decreases in the order $\mathrm{Ru}>\mathrm{Ir}>\mathrm{Pd}$, while for the oxidation of p-chlorophenol, Qin et al. [48] found out that catalytic activity decreases in a reverse order $\mathrm{Pt}>\mathrm{Pd}>\mathrm{Ru}$. Occasionally, synergistic effects in bimetallic catalysts improve catalyst activity and/or selectivity. Better $\mathrm{N}_{2}$ selectivity was achieved during ammonia oxidation when a mixed $\mathrm{Ru}-\mathrm{Pd} / \mathrm{CeO}_{2}$ catalyst was used [40]. Promoters have also been used with noble metal catalysts.

The noble metal support also influences significantly catalyst performance. Metal oxides, like alumina, ceria, titania and zirconia, as well as active carbon or high specific area graphite have been mainly studied. In the treatment of Kraft bleach effluents increasing the support surface area had a positive effect on catalyst activity [49]. The dispersion of the active phase was also shown to be important for the CWAO of oxalic acid, as demonstrated by a comparative study of two $\mathrm{Pt} / \mathrm{Al}_{2} \mathrm{O}_{3}$ catalysts prepared in different manners [50].

\subsubsection{Metal Oxides based Catalysts}

The other broad family of catalysts used in CWAO is the pure or mixed metal oxides. Copper oxide, alone or combined with other oxides, has received special attention in the CWAO of aqueous effluents [8]. Kinetics of the wet oxidation of formic acid were investigated on $\mathrm{CuO}-\mathrm{ZnO}$ catalyst [51]. Levec and Pintar [51] used a catalyst combining $\mathrm{Cu}, \mathrm{Mn}$ and $\mathrm{La}$ oxides supported on $\mathrm{Al}_{2} \mathrm{O}_{3}$ and $\mathrm{ZnO}$ to oxidize acetic acid. Ceria oxide, manganese-ceria mixed oxides and promoted ceria catalysts have also exhibited high activities. Imamura and co-workers [15] developed $\mathrm{Mn} / \mathrm{Ce}$ oxide catalysts for the CWAO of ammonia, which proved to be very effective for most organic compounds. De Leitenburg et al. [52] reported that ternary mixed oxides with ceria zirconia and $\mathrm{MnO}_{\mathrm{x}}$ or $\mathrm{CuO}$ performed better than ceria, or ceria-zirconia catalysts alone. Imamura et al. [15] studied oxidation of oxalic at $385-433 \mathrm{~K}$ by using $\mathrm{Co} / \mathrm{Bi}[5 / 1]$ complex catalyst. They have observed about $30 \%$ TOC removal at $413 \mathrm{~K}$. The performance of the catalyst was further improved by the incorporation of potassium [53], although this modification mainly affected catalyst stability. Metal oxide catalysts not based on copper or cerium have been tested in fewer cases. The use of ferric oxide gave reproducible results for the oxidation of acetic acid under severe conditions $\left(\mathrm{T}>250^{\circ} \mathrm{C}, \mathrm{P}>6.7 \mathrm{MPa}\right)$, while the copper based catalysts suffered severe deactivation [51].

A wide range of supported noble metals, mixed metal oxides, as well as active carbon alone have been shown to exhibit catalytic activity for the oxidation of aqueous solutions of organic pollutants. Noble metal catalysts are very effective for the removal of refractory carboxylic acids. For both noble metal and mixed oxide catalysts analysis of the outlet solution for dissolved metals should be always carried out to measure the degree of stability of the catalyst. Long term runs in continuous reactor should also be tested to validate catalyst stability under continuous operation conditions.

\section{Mechanisms and Reaction Pathways of CWAO}

Many attempts have been made to study reaction mechanisms for pure organic compounds during liquid phase oxidation. For engineering purposes, it is important to quantify the reaction rate by identifying the major oxidation pathways as well as understanding the reaction controlling steps. Knowledge of the reaction pathway also offers the possibility of manipulation of the oxidation to allow more complete destruction of waste organic compounds in water, or perhaps the preferential production of a particular product through appropriate variation of the process conditions. According to Gallezot [54], catalytic oxidations of organic molecules can proceed via different mechanisms, namely: (1) enzymatic oxidation, (2) free radical auto-oxidations initiated by transition metal cations, (3) metal ion oxidation of coordinated substrates, (4) oxygen transfer to the substrate mediated by metaloxo or peroxo complexes and (5) oxidative dehydrogenation on metal surfaces. In oxalic acid oxidations, oxidative dehydrogenation on metal surfaces is commonly reported [54]. The mechanism of oxalic acid oxidation on a noble metal catalyst involves the dehydrogenation of the organic substrate on the metal surface, while oxygen is needed to scavenge the adsorbed hydrogen from the surface.

\subsection{Dehydrogenation of Oxalic Acid on Platinum Surface}

Dehydrogenation occurs by chemisorption of the oxalic acid on platinum surface. There are two types of chemisorption processes. The broadest division is between molecular chemisorptions (in which all atoms linked in the original molecule remain linked in the chemisorbed form) and dissociative chemisorptions (in which the original molecule gives rise to separated adsorbed fragments on the surface. Molecular chemisorption is usually restricted to molecules possessing multiple bonds: on the simplest view, abstraction of say two of the electrons from the multiple bonds to form new bonds to the surface will not destroy the linkage between the atoms.

As shown in Figure 4, adsorption of oxalic acid on a platinum crystal surface at temperatures below about $315 \mathrm{~K}$, losses two electrons from its bond between two carbon atoms to the $\sigma$-bonds which form between the carbon atoms and the platinum atoms at the surface. This process is accompanied by rehybridization at the carbon atoms to produce four tetrahedrally directed bonds corresponding to $s p^{3}$ hybridization.

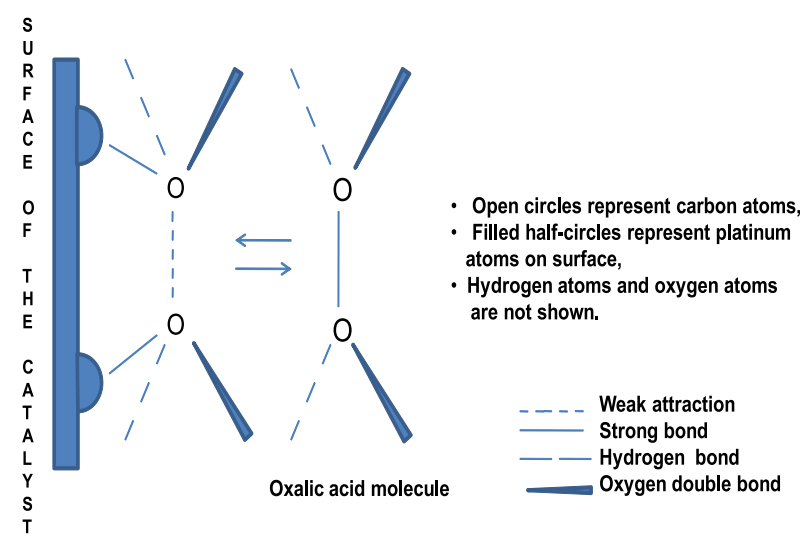

Figure 4. Adsorption of oxalic acid on platinum surface [47] 
Oxalic acid and its derivatives have been the subject of many studies in CWAO as a model reaction. Studies on the mechanisms for oxidation of oxalic acid require some knowledge of the shortlived intermediates as well as the final reaction products. For transition metal oxide catalysts, the reaction is believed to occur by free-radical initiation on the catalyst surface, homogeneous propagation, and either a homogeneous or a heterogeneous termination process. Radical initiation could occur by molecular adsorption of oxalic acid on the catalyst [13].

Generally, the reaction intermediates reported on oxalic acid oxidation catalyzed by supported metal oxides, like copper, zinc, manganese and other metal catalysts, like platinum, zinc are similar to those of non-catalyzed oxalic acid oxidation. While platinum catalysts have the potential to change the reaction pathways of organic compounds to the desired end products, $\mathrm{CO}_{2}$ and $\mathrm{H}_{2} \mathrm{O}$ [13], there is still limited information on the oxidation routes as well as the catalytic mechanisms.

\subsection{Oxidizing Agents}

The type of oxidant for a given organic compound may influence both the reaction mechanism and pathway. The most reported oxidizers for oxidation of dilute aqueous solutions of organic compounds are: hydrogen peroxide, the hydroperoxyl radical, the hydroxyl radical, the ozone radical ion, ozone and atomic oxygen. In wet oxidation reactions, the two commonly used oxidants have been oxygen (either molecular oxygen or in air) and hydrogen peroxide. Other oxidizers are widely used in advanced oxidation processes (AOP's) due to the fact that these processes aim at in-situ production of the oxidizers.

In CWAO, water with dissolved oxygen is used to oxidize the target compound. The main reactions are described in equations 1-8. Hydroxyl radicals are produced from the dissociation and oxidation of water according to equations 1 and 2. Hydroperoxyl radicals are formed from the oxidation of water (equation 2) and the target compound $\mathrm{C}_{2} \mathrm{H}_{2} \mathrm{O}_{4}$ (equation 6). Hydroxyl radicals are also produced from hydrogen peroxide (equation 4) and from the reaction of atomic oxygen with the target compound (equation 8). Hydrogen peroxide is produced by the recombination of hydroperoxyl radicals (equation 3) or by the reaction of hydroperoxyl radicals with the target compound (equation 7). Atomic oxygen is produced from the dissociation of oxygen (equation 5). Although the hydroperoxyl radical is less reactive than the hydroxyl radical, it plays an important role because of its relative abundance.

$$
\begin{aligned}
& \mathrm{H}_{2} \mathrm{O} \rightarrow \mathrm{OH}+\mathrm{H} \\
& \mathrm{H}_{2} \mathrm{O}+\mathrm{O}_{2} \rightarrow \mathrm{OH}+\mathrm{HO}_{2} \\
& 2 \mathrm{HO}_{2} \rightarrow \mathrm{H}_{2} \mathrm{O}_{2}+\mathrm{O}_{2} \\
& \mathrm{H}_{2} \mathrm{O}_{2} \rightarrow 2 \mathrm{OH} \\
& \mathrm{O}_{2} \rightarrow 2 \mathrm{O} \\
& \mathrm{C}_{2} \mathrm{H}_{2} \mathrm{O}+\mathrm{O}_{2} \rightarrow \mathrm{C}_{2} \mathrm{HO}_{4}+\mathrm{HO}_{2} \\
& \mathrm{C}_{2} \mathrm{H}_{2} \mathrm{O}_{4}+\mathrm{HO}_{2} \rightarrow \mathrm{C}_{2} \mathrm{HO}_{4}+\mathrm{H}_{2} \mathrm{O}_{2} \\
& \mathrm{C}_{2} \mathrm{H}_{2} \mathrm{O}_{4}+\mathrm{O} \rightarrow \mathrm{C}_{2} \mathrm{HO}_{4}+\mathrm{OH}
\end{aligned}
$$

During catalytic wet air oxidation (CWAO), oxygen may participate in reaction either as an adsorbed species on the catalyst surface or as a part of the lattice oxygen present in metal oxides [29]. Both free radical (homolytic) and ionic (heterolytic) oxidation reaction mechanisms have been proposed for the oxidation of aromatic compounds, resulting in a ring-opening reaction.

\subsection{Catalyst Deactivation}

In metal-catalyzed oxidations there is a risk of irreversible deactivation due to modifications of the metal phase in the course of reactions such as metal sintering (growth of particle size leading to a decrease of the active surface area) or metal leaching away in solutions. Characterization of platinum and palladium catalysts prepared by ion-exchange indicated little change in metal dispersion after glyoxal or glucose oxidation $[45,54,55]$. Schuurman et al. [55] reported a moderate sintering after five recyclings of platinum catalysts in methyl-a-glucoside oxidation which was explained by a mechanism of dissolution of the smallest particles and redeposition on the larger. Metal leaching, particularly of electropositive metal promoters is of serious concern, especially when large amounts of promoters are used. In oxidation on metals, the specific cause of deactivation is the so-called oxygen poisoning of the metal surface. It is widely accepted that the metal surface of the working catalyst is partially covered by chemisorbed oxygen forming strong Pt-O (or Pt-OH) bonds. The oxygen coverage of the surface will depend upon the relative affinity of the metal for oxygen and for the organic substrate. Dehydrogenation of the latter upon adsorption yields dissociated hydrogen which is scavenged by the chemisorbed oxygen to yield water. This can also be accounted for by redox equilibria involving surface metal atoms, with oxygen acting as oxidant and the carbohydrate as reducing agent. This dynamical balance of competitive adsorption controls the reaction rate both initially, and as reaction proceeds. The equilibrium tends to shift towards overwhelming oxygen coverage as the concentration of the substrate in solution decreases, which poisons the reaction. However, Mallat et al. [44] pointed out that the presence of strongly adsorbed reaction products or by-products block part of the surface thus producing a genuine deactivation which ultimately favors surface over-oxidation resulting in a much greater deactivation. The factors which affect the initial rate and subsequent deactivation are:

(1) Factors depending on the catalyst: (a) Metals with a higher redox potential will be less prone to oxidation [45, 54, 55]. In that respect, among Pt-group metals, platinum catalysts will be the less easily poisoned by over-oxidation, followed by palladium. (b) Small metal particles (e.g., $<2 \mathrm{~nm}$ ) deactivate more readily than larger ones, as shown in the oxidation of methyl-a-D-glucoside on platinum catalyst [55]. (c) Mass transfer limitation in catalyst pores may help prevent deactivation as demonstrated by van Dam et al. with their model of diffusion stabilized catalysts [56]. In the course of oxidation reaction on porous extrudates where metal particles are uniformly distributed in pores, the concentration of oxygen decreases continuously from the edge to the core of the extrudates; therefore, there is always a zone at a certain depth, where the concentration of oxygen is optimum to avoid metal surface over-oxidation. 
(2) Factors depending on the species in solution: (a) The higher the affinity of the carbohydrate for the metal, the lower the oxygen coverage. Thus, the absence of poisoning in the oxidation of 5-hydroxymethylfurfural on various platinum-group metals (including ruthenium, which is more prone to surface over-oxidation because of its comparatively low redox potential), was attributed to the strong bonding of the substrate via the $\pi$-electrons of the furan ring. (b) The higher the reduction potential of the substrate, the lower will be the deactivation. Thus, no deactivation occurs for the oxidation of strong reductors like glyoxal [54]. The deactivation should be lower for an aldehyde than for a primary alcohol, which accounts for more severe deactivation problems in the case of gluconate or methyl-a-o-glucoside than for D-glucose. (c) Initial activity as well as deactivation depends markedly upon the $\mathrm{pH}$ : lower rates and high deactivation are observed for reactions run at acidic $\mathrm{pH}$ because undissociated carboxylic acids are very strongly adsorbed on metals. They can poison the reaction, directly by blocking the surface, and indirectly by favoring overoxidation processes. Not only reactants and main reaction products are involved but also any by-products such as diacids produced by further oxidation and rupture of the parent carbohydrate molecule. Obviously, any kind of molecules known to poison metal surfaces (e.g., sulfur compounds) will contribute to the deactivation.

(3) Factors depending on the reaction conditions: The higher the oxygen pressure in the liquid phase, the greater the risk of over-oxidation. If the initial rate of oxidation is fast enough, oxygen dissolved in the aqueous solutions will be totally consumed (the reaction rate is then limited by gas-liquid oxygen mass transfer) and the risk of over-oxidation is weak. For sluggish reaction, over-oxidation can be prevented by working at low and constant concentration of oxygen by dilution with nitrogen or by taking advantage of mass transfer limitation in pores (vide supra). Monitoring the electrochemical potential of the catalyst to control the optimum oxygen supply is a good way to cope with this problem [44].

\subsubsection{Deactivation of Platinum Catalysts}

Catalyst deactivation is a major concern for catalyst users and manufactures. Although there is little information on the application of platinum catalysts for the oxidation of organic wastes in water, comprehensive reviews $[44,45]$ report deactivation of platinum metal catalysts during liquid phase oxidation of alcohols and carbohydrates. The possible mechanisms for deactivation include: sintering of metal particles, leaching of active components, poisoning of active sites by reactants or by-products, metal oxidation, inactive metal or metal oxide deposition. It is most likely that all deactivation mechanisms lead to a decrease in the active platinum surface area and hence to a decrease in the reaction rate.

It is, however, important to note that the reaction medium and conditions, such as $\mathrm{pH}$, reactants, intermediates and end products, all play an important role in the activity and selectivity decay of the catalyst. The deactivation of metal catalysts also depends on the reducing potential of the organic compound, e.g. the deactivation is much lower for aldehyde than for alcohols [Gallezot, 1997]. It has also been reported, for example, that the dissolution of platinum ions is enhanced in the presence of carbohydrates, because they can act as a sequestering agent. The balance of the reactants on the metal surface during aqueous phase oxidation is also important since the organic compound and oxygen are both adsorbed on the metal surface, as explained in the literature [54].

The deactivation of the catalyst by over-oxidation is caused by the exposure of the platinum surface to oxygen, resulting in the formation of inactive surface platinum oxide [56]. This type of deactivation depends on the composition, structure and texture of the catalyst. The sintering of metal particles is caused by the migration and redeposition of atoms leading to particle growth (Ostwald ripening) and a smaller active platinum surface. Schuurman et al. [55] also observed leaching of platinum metal from $\mathrm{Pt} / \mathrm{C}$ during oxidation of carbohydrates. They also found it to be dependent on the reaction medium, such as the oxidation potential and the acidity of the solution. Catalytic site covering or blocking is caused by deposition of carbonaceous species such as polymeric and byproducts on the surface of the metal catalyst, which prevents the reactant access.

Several remediation steps for catalyst deactivation have been suggested in the literature. According to Mallat and Baiker [44], the vulnerability of noble metals to poisoning can be changed by the addition of promoters such as $\mathrm{Bi}, \mathrm{Pb}$ and $\mathrm{Sn}$. Furthermore, it has been suggested that promoters also can protect noble metals against over-oxidation [45].

\section{CWAO in Bubble Column Reactor}

An important application area of bubble columns is their use as CWAO reactors .Bubble column reactors (BCRs) are multiphase reaction devices in which a discontinuous gas phase moves in form of bubbles relative to a continuous liquid phase. Eventually, a reactive solid or catalyst is fluidized in the liquid phase. The bubble column reactor is generally a vertical cylinder where the gas enters at the bottom through a gas sparger. The liquid (slurry) phase can be fed batchwise or continuously to the reactor. Continuous bubble column reactor can be operated cocurrently and counter currently. Compared with other multiphase contactors (stirred vessels, packed towers, trickle bed reactors etc.) the bubble column rector offers some advantages such as: low maintenance due to simple construction and no problems with sealing due to the absence of moving parts, high liquid (slurry) phase content for the reaction to take place, excellent heat transfer properties and, hence, easy temperature control, reasonable interphase mass transfer rates at low energy input, solids can be handled without serious erosion or plugging problems, the durability of the catalyst or other packing material is high.

Moreover, online catalyst addition and withdrawal ability and plug-free operation are other advantages that render bubble column as an attractive reactor choice [57]. Disadvantages are, however, considerable back mixing in both the continuous liquid (slurry) phase and the dispersed gas phase, high pressure drop if operated at atmospheric conditions and bubble coalescence.

\subsection{Bubble Column Reactor (BCR) Set Up}

Atmospheric air is passed from compressor as oxygen source to air 
tank. Then it is passed to saturator filled with the same liquid which is used in bubble column reactor to maintain the uniform concentration of oxalic acid in bubble column reactor. The saturated air is passed through the mass flow controller (or rotameter). Electric heater is used to heat the saturated air according to the reactor temperatures. The heated air is passed through sparger as continuous phase to the bottom of the reactor as shown in figure 5 .

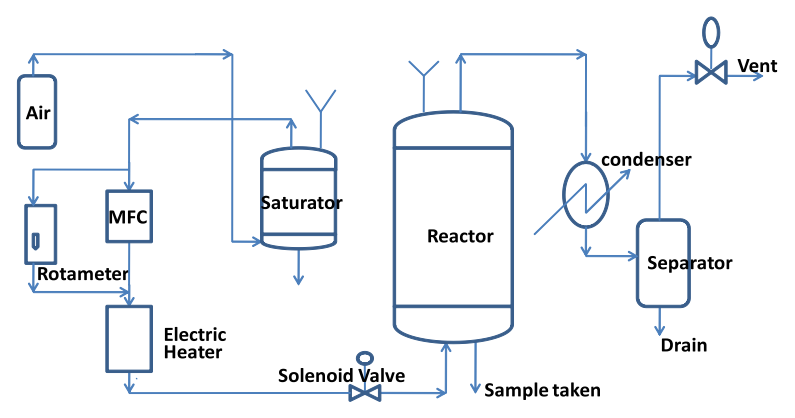

Figure 5. Process flow diagram of bubble column reactor

As the bubble column reactors provide both large relative liquid holdup and sufficient mass transfer rates, they are particularly well suited for gas-liquid reactions taking place in the slow reaction-absorption regime. Indeed, the majority of oxidations, hydrogenations, chlorination etc. carried out by industry belong to the slow reaction-absorption regime.

Though BCRs are simple in their operation and constructions, their design and scale-up can be a difficult task. In general, reactor performance is governed by reaction specific quantities and reactor specific phenomena. While the reaction specific data such as physical properties, stoichometry, thermodynamics, kinetics etc are independent of reactor type and design, the reactor specific phenomena are largely dependent on operating conditions, physical properties, reactor type and its geometrical dimensions

Specific aqueous wastes (process wastewater and domestic sludge) having an organic load ranging from 10 to $80 \mathrm{~kg} \mathrm{COD} / \mathrm{m}^{3}$ are easily treated by CWAO. The basic idea is to enhance the contact between molecular oxygen (pure or from air) and the organic matter to be oxidized [30]. The high temperature conditions favor the conversion to carbon dioxide, while the liquid phase is maintained by the high pressure, which also increases the concentration of dissolved oxygen and thus the oxidation rate. Typical values are $200-325^{\circ} \mathrm{C}$ for temperature, $50-150$ bars for pressure (higher than the vapor pressure of water at these temperatures) and $1 \mathrm{hr}$ for the residence time.

\subsection{Design and Scale-up of BCR}

In order to design bubble column reactors, following hydrodynamic parameters are required: specific gas-liquid interfacial area, axial solids dispersion coefficients, mean bubble diameter, axial dispersion coefficients of the gas and liquid, overall heat transfer coefficient between slurry and immersed heat transfer internals, mass transfer coefficients for all the species, gas holdups, and physicochemical properties of the liquid medium. In order to estimate these design parameters for the system, experimental studies ben- efit from specialized measuring devices and accessories. The gas flow into the column is measured via rotameter and the superficial gas velocity is adjusted. The gas is distributed by a gas distributor, which has different alternatives such as ring type, perforated plate or arm distributor. An electric heater can be installed to maintain constant temperature in the column. The pressure measurement system may contain liquid manometers or pressure transducers (pressure transmitters). Pressure measurements are used to estimate gas holdup in the system. Thermocouples are used wherever temperature variation is needed to be recorded. Heat flux sensors may be used to estimate the heat flux and to measure the corresponding heat transfer coefficients between the heated immersed object and slurry or the slurry and wall.

\subsubsection{Fluid Dynamics and Regime Analysis}

The fluid dynamic characterization of bubble column reactors has a significant effect on the operation and performance of bubble columns. According to literature, the experimental results obtained by parameter investigations, strictly depend on the regime prevailing in the column. The flow regimes in bubble columns are classified and maintained according to the superficial gas velocity employed in the column. Three types of flow regimes commonly observed in bubble columns are the homogeneous (bubbly flow) regime; the heterogeneous (churn-turbulent) regime and slug flow regime (Figure 6) [58].

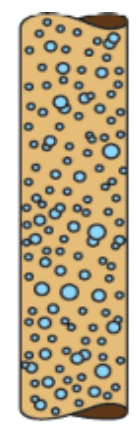

Bubble Flow

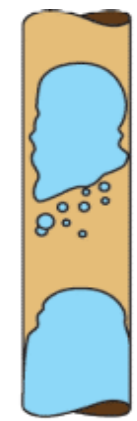

Slug or Plug Flow

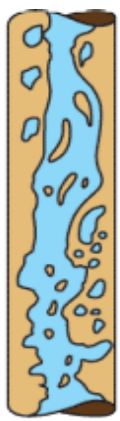

Churn Flow

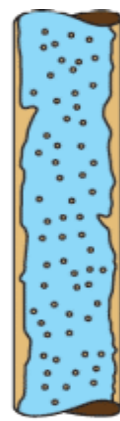

Annular Flow
Figure 6. Schematic of possible flow regimes in bubble columns [60]

There also exists the so-called "foaming regime" which is not so commonly encountered in bubble columns. The bubbly flow regime, also called the homogeneous flow regime is obtained at low superficial gas velocities, approximately less than $5 \mathrm{~cm} / \mathrm{s}$ in semi batch columns. This flow regime is characterized by bubbles of relatively uniform small sizes and rise velocities. A uniform bubble distribution and relatively gentle mixing is observed over the entire cross-sectional area of the column [58]. There is practically no bubble coalescence or break-up, thus bubble size in this regime is almost completely dictated by the sparger design and system properties [59]. The churn-turbulent regime, also called the heterogeneous regime is maintained at higher superficial gas velocities (greater than $5 \mathrm{~cm} / \mathrm{s}$ in batch columns) (Figure 7). This regime is characterized by the disturbed form of the homogeneous gas-liquid system due to enhanced turbulent motion of gas bubbles and liquid recirculation. As a result unsteady flow patterns and 
large bubbles with short residence times are formed by coalescence due to high gas throughputs. This flow regime is thus sometimes also referred as coalesced bubble flow regime, indicating the much different sizes of the bubbles. As a matter of fact, by bubble coalescence and break-up, a wide bubble size distribution is attained. The average bubble size is governed by coalescence and breakup which is controlled by the energy dissipation rate in the bulk [59]. Vigorous mixing, bubble cluster formation and wide bubble size range were also pointed out by Hyndman et al. [58]. Churnturbulent flow is frequently observed in industrial-size, large diameter columns. It has been shown that the gas-liquid mass transfer coefficient is lower at churn-turbulent (heterogeneous) regime as compared to homogeneous flow.

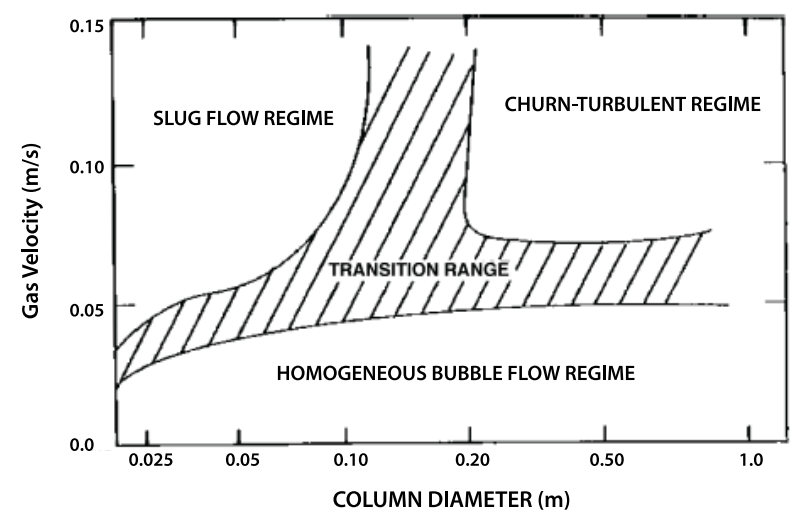

Figure 7. Flow regime map for bubble columns [60]

A slug flow regime has been only observed in small diameter laboratory columns at high gas flow rates [58]. This regime takes its name from the formation of bubble slugs when larger bubbles are stabilized by the column wall. Figure 7 illustrates the differences between the possible regimes discussed. The detection of regime transition from homogeneous to churn-turbulent flow and the investigation of the transition regime are quite important. As the transition takes place, significant changes are observed in the hydrodynamic behavior of the system. There exists an onset of upward liquid circulation in the column centre and downward liquid circulation near the column wall. As a result more gas entry takes place in the centre, leading to build-up of transverse holdup-profile that enhances liquid circulation. Recently, Thorat and Joshi [59] reported that the transition gas velocity depends on column dimensions (diameter, dispersion height), sparger design and physical properties of the system.

In order to characterize the flow regimes, unfortunately it is not possible to give definite quantitative ranges for superficial velocities. Different studies performed with different systems and operating conditions provide different results in determination of regime boundaries and regime transitions [60]. For instance Hyndman et al. [58] proposed that below $4 \mathrm{~cm} / \mathrm{s}$ superficial velocity a bubbly flow regime prevails. Pino et al. [61] also reported approximately the same velocity for a bubbly flow regime. Bukur and Daly [62] observed the churn-turbulent flow regime for gas superficial velocities between 2 and $5 \mathrm{~cm} / \mathrm{s}$. Several flow regime charts have been presented in literature to identify the boundaries of possible flow regimes [63]

\subsubsection{Gas Holdup}

Gas holdup is a dimensionless key parameter for design purposes that characterizes transport phenomena of bubble column systems [64]. It is basically defined as the volume fraction of gas phase occupied by the gas bubbles. As reported by Li and Prakash [65] in a three-phase slurry bubble column, the static pressure drop along the bed height can be expressed as

$\Delta P=\left(\rho_{g} \varepsilon_{g}+\rho_{l} \varepsilon_{l}+\rho_{s} \varepsilon_{s}\right) g \Delta H$

In the above equation, $\varepsilon_{\mathrm{g}}, \varepsilon_{\mathrm{I}}$ and $\varepsilon_{\mathrm{s}}$ are the volume fractions of gas, liquid and solid phases, respectively. $\varepsilon_{\mathrm{g}}$ is called the gas holdup, g, $\rho$ and $\Delta H$ are the gravitational acceleration, the density and height difference between the transducers, respectively. The subscripts g, 1 and s stands for gas, liquid and solid phases. By proper substitutions, starting with Eq. (1), the gas holdup is

$\varepsilon_{g}=1-\frac{1}{g\left(\rho_{l} \varphi_{l}+\rho_{s} \varphi_{s}\right)} \frac{\Delta P}{\Delta H}$

Eq. (2) can be directly applied for estimation of gas holdup in a slurry bubble column. The most widely used technique in estimating gas holdup is the pressure profile method which is based on measuring the static pressure at two or more points along the column using manometers or more recently pressure transducers and thus obtaining the pressure drop, $\Delta P$ along the bed [63].

\subsubsection{Superficial Gas Velocity}

Superficial gas velocity is the average velocity of the gas that is sparged into the column which is simply expressed as the volumetric flow rate divided by the cross-sectional area of the column. Gas holdup in bubble columns depends mainly on superficial gas velocity. For both bubble columns and slurry bubble columns, gas holdup has been found to increase with increasing superficial gas velocity $[61,65]$. This increase has been found to be proportional to superficial gas velocity in the bubbly flow regime. For the churn turbulent regime, the effect of superficial velocity on gas holdup is less pronounced. Recently Veera et al. [66] reported an experimental study based on investigation of effect of gas velocity on gas holdup profiles in, foaming liquids. They observed that the superficial gas velocity has a large influence on radial holdup profile at high foaming agent concentrations

\subsubsection{Liquid Phase Properties}

The liquid phase property has an impact on bubble formation and/ or coalescing tendencies and hence is an important factor affecting gas holdup. An increase in liquid viscosity results in large bubbles and thus higher bubble rising velocities and lower gas holdup [65]. It is also reported that adding a small amount of surfactant to liquid, results in significantly higher gas holdup values. Moreover, the presence of electrolyte or impurities also increases gas holdup. Recently, Tang and Heindel [67] suggested that regular tap water, 
which is the most frequently used liquid in bubble columns, might cause significant reproducibility problems in air-water two phase studies. They observed time-dependent variation of gas holdup which was then related to water quality, column operation mode, sparger orientation and superficial gas and liquid velocities. They attributed this time-dependency to coalescence inhibition caused by the existence of volatile substances present in tap water.

\subsubsection{Operating Conditions}

The effect of operating pressure and temperature on gas holdup of bubble columns were also investigated in many studies [63, 64]. It is commonly accepted that elevated pressures lead to higher gas holdups. Empirical correlations have been proposed for gas holdup in bubble columns operated at high pressure and temperature [65]. Luo et al. [64] carried out experiments at about 5.6 MPa, to investigate the effect of pressure on the hydrodynamics of a slurry bubble column and found that gas holdup increases with pressure and the pressure effect is more pronounced in higher concentration slurries. The operating temperature is another important factor to be discussed. Although most studies conclude that the temperature effect is not so significant, some disagree with this argument.

\subsubsection{Column Dimensions}

The effect of column diameter and height on hydrodynamics is also widely investigated in literature. Luo et al. [64] reported that the influence of the column height is insignificant if the height is above 1-3 $\mathrm{m}$ and the ratio of the column height to the diameter (aspect ratio) is larger than 5. Possible wall effects brought about by the use of small diameter columns $(\leq 10 \mathrm{~cm})$ were also pointed out [65].It was reported that the gas holdup was not highly dependent on column diameter when the column diameter was larger than $10 \mathrm{~cm}$, as long as mixing was well maintained. Daly et al. [62] found that the holdup is independent of the column height. Additionally, though not so significant, they obtained some differences in holdup with variation of the column diameter. It was observed that the holdup in small diameter column was slightly higher than that in larger diameter columns. The effect of column dimensions on gas holdup in foaming systems has not received significant attention in literature. According to the two-phase model developed by Krishna et al. [68] the effect of column diameter on gas holdup should be separately analyzed for small and large bubble gas holdups. It was found out that the small bubble gas holdup is independent of column diameter, while the large bubble gas holdup decreased with increasing column diameter. As a result the overall holdup is reported to decrease with increasing column diameter due to large bubble holdup.

\subsubsection{Gas Sparger}

Gas sparger type is an important parameter that can alter bubble characteristics which in turn affects gas holdup and thus many other parameters characterizing bubble columns. The sparger used determines the bubble sizes observed in the column. Small orifice diameter plates enable the formation of smaller sized bubbles. Some common gas sparger types that are used in literature studies are perforated plate, porous plate, membrane, ring type distributors and arm spargers. Bouaifi et al. [60] stated that, the smaller the bubbles, the greater the gas holdup values. Thus, they concluded that with small orifice gas distributors gas holdup values were higher. In another study by Luo et al. [64], gas holdup was found to be strongly affected by the type of gas distributor. The effect was more pronounced especially for gas velocities below $6 \mathrm{~cm} / \mathrm{s}$.

\section{Conclusions}

The design of a CWAO bubble column reactor is a complex process as the performance depends on many parameters like flow conditions, liquid and gas circulation and axial dispersion, mass transfer, thermodynamic properties of the phases, equilibrium constants and kinetic parameters. It has been shown that temperature, pressure, inert gas flow rate and $\mathrm{pH}$ evolution during oxidation are important parameters to be taken into account when predicting the performance of a wet air oxidation unit.

Although complementary studies could be made necessary by the specificity of the conditions (temperature, pressure, etc.) and by the variety of wastes to be treated. But because of the high sensitivity to gas hold-up, it could be interesting to obtain new data under the very specific conditions of the CWAO process.

\author{
Abbreviation \\ AOP: Advance Oxidation Process \\ AWV: Atmospheric Water Vapor \\ CWAO: Catalytic Wet Air Oxidation \\ EASF: Easily Accessible Surface Fresh water \\ MFC: Mass Flow Controller \\ SCWO: Super Critical Water Oxygen \\ TOC: Total Organic Compound \\ UNEP: United Nations Environmental Program \\ WAO: Wet Air Oxidation \\ WET OX: Wet Oxidation \\ WWLO: Water within Living Organisms. \\ WMO: World Meteorological Organization
}




\section{References}

1. P. A. G. M Scheren, Ph D thesis, Eindhoven University of Technology (2003).

2. I. A. Shiklomanov, Comprehensive Assessment of the Freshwater Resources of the World: Assessment of Water Resources and Water Availability in the World: World Meteorological Organization and Stockholm Environment Institute, Stockholm, Sweden, pp. 34-36 (1997)

3. UNEP/GEMS (United Nations Environment Program Global Environment Monitoring System/Water). (1995) Water Quality of World River Basins. Nairobi, Kenya: UNEP., pp. 33-35.

4. P. Patnaik, A Comprehensive Guide to the Hazardous Properties of Chemical Substances, 2nd Edn., Wiley, New York pp. 835-865 (1999).

5. F. L. Coe, A. Evan and E.Worcester, Journal of Clinical Investigation. 115, 2598 (2005)

6. M. Morozumi, R. Z. Hossain, K. I. Yamakawa, S. Hokama, S. Nishijima, Y. Oshiro, A. Uchida, K. Sugaya and Y. Ogawa, Urological Research, 34, 168 (2006).

7. U. Pabuccuoglu, Journal of Pathology Research and Practice, 201, pp. 363 -368 (2005)

8. J. C. Lieske, D. S. Goldfarb, C. De. Simone and C. Regnier, Journal of Kidney International, 68, 1244 (2005).

9. Metcalf \& Eddy, Wastewater Engineering: Treatment, Disposal and Reuse. McGraw-Hill, New York 3rd ed (1991).

10. T. C. Voice, Activated carbon adsorption, Standard Handbook of Hazardous Waste Treatment and Disposal, McGraw-Hill, New York pp.230-233 (1988).

11. J. J. Santoleri, Liquid-Injection Incinerators, Standard Handbook of Hazardous Waste Treatment and Disposal, McGraw-Hill, New York pp. 216224 (1988).

12. S. C. Rowat, Medical Hypotheses, 52, 389 (1999).

13. V. S. Mishra, V. V. Mahajani and J. B. Joshi, Ind. Eng. Chem. Res., 34, 2 (1995)

14. R. Andreozzi, V. Caprio and R. Insola Marotta, Catalysis Today, 53, 51 (1999).

15. S. Imamura, Ind. Eng. Chem. Res., 38, 1743 (1999).

16. R. J. Bigda, Chem. Eng. Prog., 91, 62-66 (1995).

17. A. Fortuny, C. Bengoa, J. Font and A. Fabregat, Journal of Hazardous Materials, 64-2, pp. 181-193 (1999).

18. S. Hamoudi, F. Larachi and A. Sayari, J. Catalysis, 177, 247 (1998).

19. Z. Y. Ding, M. A. Frisch, L. Li and E. F. Gloyna, Ind. Eng. Chem. Res., 35, 3257 (1996).

20. D. R. Grymonpre, W. C. Finney and B. R. Locke, Chem. Eng. Sci., 54, 3095 (1999)

21. Y. G. Adewuyi, Ind. Eng. Chem. Res., 40, pp. 4681-4715 (2001).

22. P. E. Savage, S. Gopalan, T. I. Mizan, C. J. Martino and E. E. Brock, AIChE J., 41, pp. 1723-1778 (1995).

23. S. Degaleesan, M. Dudukovic and Y. Pan, AIChE J., 47, pp. 1913-1931 (2001).

24. H. Schmieder and J. Abeln, Chem. Eng. Technol., vol. 22, 11, pp. 903-908 (1999).

25. R. Andreozzi, A. Insola, V. Caprio, R. Marotta, V. Tufano, Appl. Catal. A General, 138, 75 (1996).

26. G. Gündüz and M. Dükkanci, International Journal of Chemical Reactor Engineering, Vol. 5, Article A36 (2007).

27. M. Dükkanci and G. Gündüz, Catalysis communications, 10, 913-919 (2009).

28. A. Sadana and J. R. Katzer, J. Catal., 35, 140 (1974).

29. Y. Matatov-Meytal and M. Sheintuch, Ind. Eng. Chem. Res., 37, 309 (1998).

30. F. J. Zimmermann and D.G. Diddams, TAPPI, 43, pp. 710-715 (1960).

31. S. T. Kolaczkowski, P. Plucinski, F. J. Beltran, F. J. Rivas and D. B. McLurgh, Chem. Eng. J.,73, pp. 143-160 (1999).

32. F. Luck, Catalysis Today, 27195 (1996).
33. F. Luck, Catalysis Today, 53, 81-91 (1999).

34. H. Debellefontaine, S. Crispel, P. Reilhac, F. Périé and J. N. Foussard, Chemical Engg. Science, 54, pp. 4953-4959 (1999).

35. J. Donlagic and J. Levec, Appl. Catal. B: Environment, 17, L1-L5 (1998).

36. V. Tukač and J. Hanika, J. Chem. Technol. Biotechnol., 71, pp. 262-266 (1998).

37. J. Barbier Jr., F. Delanoë, F. Jabouille, D. Duprez, G. Blanchard and P. Isnard, Journal of Catalysis, 177, pp. 378-385 (1998).

38. L. Oliviero, J. Barbier Jr., D. Duprez, A. Guerrero-Ruiz, B. BachillerBaeza and I. Rodriguez-Ramos, Appl. Catal. B: Environment, 25, 267 (2000).

39. R. Ukropec, B. F. M. Kuster, J. C. Schouten and R. A. Van Santen, Appl. Catal. B, 23, pp. 45-57 (1999).

40. J. Barbier Jr., L. Oliviero, B. Renard and D. Duprez, Catalysis Today, 75, 29 (2002).

41. W. An, Q. Zhang, Y. Ma and K. T. Chuang, Catalysis Today, 64, 289 (2001).

42. D. Duprez, F. Delanoë, J. Barbier Jr., P. Isnard and G. Blanchard, Catal. Today, 29, p. 317 (1996).

43. H. T. Gomes, J. L. Figueiredo and J. L. Faria, Applied Catalysis B: Environmental, 27, pp. L217-L223 (2000).

44. T. Mallat and A. Baiker, Catalysis Today, 19247-84 (1994).

45. M. Besson and P. Gallezot, Catalysis Today, 57, 127 (2000).

46. P. Gallezot, N. Laurain and P. Isnard, Appl. Catal. B, Environ. 9, L11 (1996).

47. M. J. Chollier, F. Epron, E. Lamy-Pitara and J. Barbier, Catalysis Today, 48, pp. 291-300 (1999).

48. J. Qin, Q. Zhang and K. T. Chuang, Appl. Catalysis B: Environment, 29, 115-123 (2001).

49. A. Pintar, M. Besson and P. Gallezot, Appl. Cat. B: Environ., 30, 123 (2001).

50. D. K. Lee and D. S. Kim, Catalysis Today, 63, pp. 249-255 (2000).

51. J. Levec and A. Pintar, Catal. Today, 24, 51 (1995).

52. C. de Leitenburg, A. Trovarelli, J. Llorca, F. Cavani and G. Bini, Applied Catalysis A: General, 139, p. 161 (1996).

53. S. T. Hussain, A. Sayari and F. Larachi, Appl. Cat. B: Environ., 34, 1 (2001).

54. P. Gallezot, Catalysis Today, 37, 405 (1997).

55. Y. Schuurman, B. F. M. Kuster, K. van der Wiele and G. B. Marin, Appl. Catal. A: General, 89, 31 (1992).

56. H. E. van Dam, P. Duijverman, A. P. G. Kieboom and H. van Bekkum, Applied Catalysis, 33, 373 (1987).

57. A. Prakash, A. Margaritis, H. Li and M.A. Bergougnou, Biochemical Engineering Journal, 9, pp. 155-163 (2001).

58. C. L. Hyndman, F. Larachi and C. Guy, Chem. Eng. Sci., 52, 63 (1997).

59. B. N. Thorat and J. B. Joshi, Journal of Experimental Thermal and Fluid Science. 28, 423 (2004).

60. M. Bouaifi, G. Hebrard, D. Bastoul and M. Roustan, Chemical Engineering and Processing, 40, pp. 97-111 (2001).

61. L. Z. Pino, R. B. Solari, S. Siquier, L. A. Estévez, M. M. Yepez and A. E Saez, Chemical Engineering Communications, 117, 367 (1992).

62. D. B. Bukur and J. G. Daly, Chem. Eng. Sci., 42, 2967 (1987).

63. L. S. Fan, A. Matsuura and S. S. Chern, AIChE J., 31, 1801 (1985).

64. X. Luo, D. J. Lee, R. Lau, G. Yang and L. Fan, AIChE J., v. 45, pp. 665685. (1999).

65. H. Li and A. Prakash, Powder Technol., 113, pp. 158-167 (2000).

66. U. P. Veera, K. L. Kataria and J. B. Joshi, Chem. Eng. J., 99, Issue 1, pp. 53-58 (2004).

67. C. Tang and T. J. Heindel, Chem. Eng. Sci., 59, 623 (2004).

68. R. Krishna, J. W. A. de Stewart, J. Ellenberger, G. B. Martina, C. Maretto, AIChE J., 43, 3647 (1997). 